\title{
PENGGUNAAN METODE DUPONT DAN RADAR DALAM HUBUNGAN DENGAN PENGUKURAN KINERJA KEUANGAN SETELAH AKUISISI \\ (Study Kasus PT Tifico Fiber Indonesia Tbk).
}

\author{
Irman Ansari) \\ 1)dosen universitas pamulang, email : irmanansari02@@gmail.com
}

\section{ARTICLES}

INFORMATION

\section{ABSTRACT}

\author{
JURNAL SEKURITAS \\ (Saham, Ekonomi, Keuangan \\ dan Investasi ) \\ Vol.1, No.4, Juni 2018 \\ Halaman : 132 - 151 \\ (c) LPPM \& Prodi Manajemen \\ UNIVERSITAS PAMULANG \\ ISSN (online) : 2581-2777 \\ ISSN (print) : :2581-2696
}

\section{Keyword :}

Economic and company fundamental, and bond price of emitten

JEL. classification :

C33, G20, G23, N65

\section{Contact Author :}

PRODI MANAJEMEN UNPAM

JL.Surya Kencana No.1 Pamulang

Tangerang Selatan - Banten

Telp. (021) 7412566, Fax (021) 7412491 Email :

jurnalfinance.unpam@gmail.com
Tujuan dari penelitian ini adalah untuk menilai kinerja keuangan PT Tifico Tbk sebelum dan setelah akuisisi oleh beberapa perusahaan konsorsium dari perusahaan Jepang PT Teijin Limited, dan memperbandingkan kinerja PT Tifico Tbk dengan kinerja beberapa perusahaan yang sejenis dalam industri polyester yang tercatat pada Bursa Efek Indonesia. Data yang digunakan sebagai bahan analisa yaitu data laporan keuangan masing masing perusahaan. Pada PT Tifico Tbk sebelum akuisisi, data laporan keuangan yang dianalisa pada periode 2006 2009, sedangkan data laporan keuangan yang dianalisa pada PT Tifico Tbk setelah akuisisi dan beberapa perusahaan industri sejenis yang tercatat pada Bursa Efek indonesia pada periode $2010 \sim 2014$. Metode penelitian yang digunakan penulis yaitu penelitian deskriptif dengan menganalisa laporan keuangan dengan data quantitatif dan teknik yang digunakan untuk penganalisaan dengan metode Dupont dan metode Radar. Hasil penelitian secara konkret dapat disebutkan penilaian kinerja perusahaan baik dengan metode Dupont maupun dengan metode Radar memperlihatkan hasil yang saling memperkuat. Hasil analisa dapat disimpulkan bahwa: PT Tifico setelah akuisisi mempunyai kinerja yang lebih baik dibandingkan dengan sebelum akuisisi dan juga lebih baik dari Perusahaan yang sejenis, namun belum dikategorikan sehat dibandingkan dengan kinerja industri secara umum.

The aim of this thesis is to to assess financial performance of PT Tifico Tbk. before anf after acquisition by the consortium of PT Teijin Limited Japan and to compare financial performance with other companies in same industry are included in main board at the Indonesia Stock Exchange. Analyzed data based on financial statement of each of company. PT Tifico Tbk. before acquisition during the period $2006 \sim 2009$, and PT Tifico Tbk after acquisition and other companies during the period 2010 2014. The used of thesis method is descriptive research by analyzing financial statement using quantitative data and analysis techniques used by Dupont Method and Radar Method. The concrete of thesis result can be concluded, judgement of financial performance a company either by dupont or radar method have the same result and strengthen it.Related with result of this thesis can be conclude, Financial performance of PT Tifico Tbk after acquisition is better than before and other companies in same industry are included in main board at The Indonesia Stock Exchange. 


\section{A. Pendahuluan}

Suatu perusahaan didirikan mempunyai tujuan yang sama yaitu mendapatkan keuntungan (laba) yang optimum dengan cara meningkatkan penjualan, menaikkan nilai saham dengan target utama meningkatkan kesejahteraan bagi investor perusahaan tersebut. Pada era globalisasi saat ini dimana persaingan bisnis antara perusahaan sangat ketat dan perkembangan perekonomian yang bisa berfuktuasi seperti kondisi saat ini berfluktuatifnya harga minyak dunia secara significant (turun tajam dari USD $90 \rightarrow$ USD 50/barrel), nilai mata uang Rupiah yang terdepresiasi tajam hingga mencapai nilai Rp 13.700/ USD serta faktor faktor lainnya mempengaruhi kondisi kekuatan atau kesehatan seluruh industri dari berbagai bidang baik manufaktur maupun industri jasa secara significant. Kondisi ini menuntut semua pelaku bisnis (usaha) berusaha bertindak sebaik mungkin guna memperoleh hasil yang optimum agar menjadi yang terbaik dalam persaingan yang super ketat seperti kondisi saat ini. Untuk menjadi yang terbaik dalam persaingan tersebut, dapat dilakukan dengan metode pengembangan usaha, berinovasi (berkreasi) dalam memproduksi yang dapat berupa diversifikasi produk untuk meningkatkan nilai tambah/jual dari produk yang ada saat ini atau membuat produk produk jenis baru, dan atau juga bisa melakukan ekspansi guna meningkatkan kinerja perusahaan agar dapat terus bersaing dan tetap bertahan dalam lingkungan industrinya. Untuk mengetahui kinerja perusahaan, ada beberapa metode menilai kinerja perusahaan diantaranya yang digunakan oleh penulis untuk menganalisa kinerja perusahaan Polyester yaitu PT Tifico sebelum dan setelah diakuisisi dan diperbandingkan dengan perusahaan Polyester lainnya yang terdaftar pada Bursa Efek Indonesia (BEl) yaitu metode Dupont dan Metode Radar. Hal yang mendasari penulis untuk melakukan penelitian terhadap PT Tifico Fiber Indonesia yaitu:

1. Perusahaan ini merupakan pioner perusahaan Polyester dan juga menguasai pangsa pasar di Indonesia hingga tahun 1990an, namun akhirnya pada tahun 2010 perusahaan ini terakuisisi oleh 4 perusahaan konsorsium yang berlatar belakang perusahaan china .

2. Adanya perobahan sistem dan gaya Managemen dari managemen perusahaan Jepang dan perusahaan china.

3. Latar belakang perusahaan konsorsium merupakan perusahaan otomotif dan tekstil, dan bukan Poleyester.

4. Response karyawan yang negatif pada perusahaan konsorsium sehingga banyak yang mengundurkan diri.

5. Dukungan Keuangan terhadap perusahaan konsorsium berasal dari internal, dan ini berbeda dengan PT Tifico sebelum akuisisi didukung oleh perusahaan Induk PT Teijin Limited Jepang.

\section{A. Perumusan Masalah}

Dari identifikasi dan pembatasan masalah di atas, maka masalah yang akan diteliti memiliki rumusan sebagai berikut:

1. Adakah perobahan kinerja sebelum dan sesudah akuisisi menggunakan metode Dupont?

2. Adakah perubahan kinerja sebelum dan sesudah akuisisi menggunakan metode Radar? 
3. Bagaimana peringkat (posisi) kinerja keuangan PT Tifico Tbk dibandingkan dengan industri polyester lainnya setelah akuisisi dilihat dari metode Dupont dan dilihat dari metode Radar serta bagaimana kondisi kinerjanya dibandingkan dengan standar umum industri lainnya ?

\section{Tujuan Penelitian}

Tujuan penelitian dengan analisa kinerja keuangan perusahaan PT TIFICO dengan metode Dupont dan metode Radar yaitu:

a. Memberikan gambaran kinerja perusahaan PT TIFICO

i. Sebelum Akuisisi,

ii. Sesudah Akuisisi.

b. Melihat Peringkat kinerja PT Tifico dibandingkan dengan perusahaan industri sejenis sesudah akuisisi.

\section{Landasan Teori}

1. Kajian Teori Relevan Yang Terkait Dengan Penelitian.

\subsection{Laporan keuangan.}

Laporan keuangan merupakan laporan pertanggung jawaban dari pimpinan perusahaan atas pengelolaan yang dipercayakan padanya. Ada beberapa definisi dari beberapa ahli tentang pengertian laporan keuangan, dari beberapa pendapat tersebut dapat disimpulkan penulis bahwa laporan keuangan merupakan laporan tentang kondisi keuangan perusahaan yang menjelaskan posisi keuangan (aset dan kewajiban serta equitas), keberhasilan dalam mencapai keuntungan dan aliran kas dalam operasional perusahaan tersebut dalam waktu periode tertentu.

\subsection{Tujuan laporan Keuangan.}

Tujuan dari dibuatnya laporan keuangan yaitu untuk memenuhi keperluan dari pihak pihak yang berkepentingan dengan perusahaan baik internal maupun eksternal. Berdasarkan definisi dari beberapa pendapat dapat disimpulkan bahwa tujuan dari pembuatan laporan keuangan sangat berguna bagi seluruh pihak yang terlibat pada perusahaan tersebut baik internal maupun eksternal dengan pemanfaatnya disesuaikan dengan keperluan masing masing pihak yang terlibat pada perusahaan tersebut.

\subsection{Analisa laporan keuangan.}

Analisa laporan keuangan merupakan untuk suatu kegiatan untuk mengurai item item pada laporan keuangan menjadi unit informasi yang bermanfaat dan melihat hubungan antara unit secara significant dan bermakna pada laporan keuangan sebelum dibuatkan kesimpulan dari laporan keuangan tersebut. 


\subsection{Metode Analisa laporan keuangan.}

Dalam mengevaluasi dan menganalisa laporan keuangan satu perusahaan maka perlu adanya suatu ukuran tertentu yang menjelaskan output pos pos ataupun parameter dari laporan keuangan. Penentuan suatu ukuran dibutuhkan alat atau metode untuk mengukurnya. Alat yang digunakan untuk mendapatkan nilai ukur itu pada analisa keuangan menggunakan metode yang disebut analisa rasio.

\subsection{Rasio Keuangan.}

Rasio Keuangan merupakan suatu cara atau metode perhitungan yang dapat memberikan informasi dan gambaran nilai atau kinerja dari aktitivitas operasional perusahaan.

\subsection{Analisa Rasio Keuangan.}

Analisa rasio merupakan salah satu metode untuk menganalisa laporan keuangan. Cara analisa dengan metode ini yaitu menggunakan perhitungan dengan cara membandingkan data data kuantitatif yang tersebut pada neraca dan laporan laba dan rugi.

\subsection{Analisa Kinerja Keuangan.}

Kinerja merupakan unjuk kerja atau hasil dari aktivitas yang dilakukan baik individu perseorangan maupun suatu lembaga termasuk didalamnya perusahaan. Sedangkan analisa kinerja merupakan evaluasi untuk mencari point yang menjadi keunggulan atau kekurangan dalam rangka untuk memperbaiki kinerjanya di masa yang akan datang.

\section{1) Metode Dupont}

Analisis rasio dengan Metode Dupont merupakan analisis untuk mengukur tingkat efektivitas perusahaan dalam memutar asetnya untuk mendapatkan keuntungan. Analisis ini dilakukan secara lengkap dan sifatnya menyeluruh. Analisis rasio Dupont ini menitikberatkan pada Return onlnvestment.Menurut Sutrisno(2003:256) Analisa Dupont adalah suatu analisa yang digunakan untuk mengontrol perobahan dalam rasio aktivitas dan net profit margin dan sebarapa besar pengaruhnya terhadap Return of Investment (ROI). Sedangkan Menurut Sawir( 2005:28), Analisa Dupont menggabungkan rasio aktivitas dan profit margin, dan menunjukkan bagaimana rasio rasio tersebut berinteraksi untuk menentukan profitabilitas aset aset yang dimiliki perusahaan. Jika rasio perputaran dikalikan dengan margin laba penjualan, hasilnya adalah tingkat pengembalian aset $(\mathrm{ROA})$ atau sering juga disebut dengan tingkat pengembalian investasi.

Berdasarkan pendapat tersebut diatas, maka ada 2 parameter yang penting pada metode dupont ini yaitu ROI dan ROE. Untuk mendapatkan nilai ROI dan ROE dilakukan dengan perhitungan sebagai berikut:

a. Total Asset Turn Over (TATO), yaitu perputaran aset yang digunakan untuk mengukur effisiensi penggunaan aset dalam menghasilkan keuntungan. 
b. Net Profit Margin(NPM), yaitu: tingkat kemampuan perusahaan dalam menghasilkan keuntungan, Nilai parameter ini menunjukkan tingkat keberhasilan management dalam mengelola operasional perusahaan. Semakin besar nilai maka akan semakin baik.

Berdasarkan data point a dan b maka dapat dihitung nilai ROI. Sedangkan Pengukuran ROE dihitung dengan tambahan menghitung item: Equity Multiplier, yaitu mengukur besarnya aset yang dibiayai oleh pemegang saham, semakin besar aset yang dimiliki pemegang saham maka beban hutang yang semakin kecil. Formula dari point a, b, EM, ROI, dan ROE yaitu:

\begin{tabular}{|c|c|l|}
\hline No & Item & \multicolumn{1}{c|}{ Formula } \\
\hline 1 & TATO & (Net sale/Total Aset) $\times 1$ kali \\
\hline 2 & NPM & (Net Income setelah pajak/Net sale) $\times 100 \%$ \\
\hline 3 & EM & (Total Aset/ Share Holder) $\times 100 \%$ \\
\hline 4 & ROI & TATO $\times$ NPM $\times 100 \%$ \\
\hline 5 & ROE & TATO $\times$ NPM $\times$ EM $\times 100 \%$ \\
\hline
\end{tabular}

\section{2) Metode Economic Value Added (EVA)}

Economic value added (EVA) adalah suatu metode penilaian kinerja keuangan. Penilaian dilakukan dengan menghitung kemampuan perusahaan memenuhi seluruh biaya operasional dan biaya modal. Seluruh biaya operasional dan biaya modal dianggap sebagai investasi untuk mendapatkan keuntungan ekonomi. Metode EVA digunakan untuk mengevaluasi kinerja keuangan, apakah perusahaan mampu memberikan nilai tambah berupa laba yang menguntungkan bagi pihak pemegang saham. Nilai tambah itu dinilai dari perbandingan biaya modal dan operasional dengan keuntungan yang didapatkan.

3) Metode Balance Scorecard

Balance Scorecard merupakan cara penilaian yang dikembangkan oleh Drs.Robert Kaplan (Harvard Business School) dan David Norton pada awal tahun 1990. Balance scorecard melakukan penilaian dalam bidang keuangan dan juga non keuangan. Lebih tepatnya terdapat empat aspek yang dinilai dengan menggunakan balance scorecard, yaitu: keuangan, customer, proses bisnis atau internal, dan pembelajaran-pertumbuhan.

4) Metode Radar

Analisa dengan metode radar ini merupakan pengembangan dari analisa rasio yang lainnya. Pada metode ini banyak hal yang dianalisa sehingga dapat memberikan gambaran yang menyeluruh tentang kinerja perusahaan dan arah perkembangannya baik dalam jangka pendek maupun jangka panjang. Analisa dengan metode radar ini dapat juga memberikan pembenaran terhadap nilai ROI yang rendah. Sebutan metode Radar berasal dari bentuk gambaran visual dari ikhtisar perhitungan rasio-rasionya. Metode Radar ini dikembangkan oleh APO (Asian Productivity Organization). Tujuannya untuk memberikan gambaran yang menyeluruh tentang perusahaan dan kemungkinan perkembangan suatu perusahaan untuk periode selanjutnya. Penilaian dengan metode Radar juga dapat digunakan untuk membaca kemungkinan adanya "Window Dressing" dari laporan keuangan, meskipun untuk 


\section{ISSN (online) : 2581-2777 \& ISSN (print) : 2581-2696}

mengetahuinya diperlukan pengalaman, kecermatan dan keterampilan dari penganalisa. Analisa rasio dengan metode Radar secara umum dapat dikelompokkan menjadi 5 Rasio, yaitu:

a. Rasio Profitabilitas, yaitu: rasio yang menunjukkan kinerja perusahaan secara umum yang terindikasi dari tingkat pencapaian keuntungan yang terkait dengan hasil penjualan dan aset yang digunakan.

b. Rasio Produktivitas, yaitu: rasio yang menunjukkan faktor produktivitas karyawan yang berada pada lingkungan perusahaan tersebut. Hal yang terkait pada rasio ini yaitu unjuk kerja karyawan pada pencapaian penjualan, nilai tambah produk (NAV) dan beban pekerjaan pada perusahaan tersebut.

c. Rasio Utilisasi Aset, yaitu: rasio yang menunjukkan tingkat efektivitas perusahaan dalam mengelola aset yang dimilikinya baik berupa perputaran inventory(persediaan) ataupun pemanfaatan aset lainnya dalam rangka untuk mencapai keuntungan yang optimal.

d. Rasio Stabilitas yaitu rasio yang menunjukkan kemampuan perusahaan dalam memenuhi kewajibannya pada waktu yang telah ditentukan. Kemampuan tersebut bisa berupa aset yang langsung dimiliki pemilki modal ataupun aset yang diperoleh berupa hutang dengan pihak ketiga.

e. Rasio Pertumbuhan yaitu rasio yang menunjukkan pertumbuhan sektor riil atau bisnis perusahaan yang terindikasi dari peningkatan pendapatan,penjualan maupun kekayaan perusahaan.

\section{Penelitian Terdahulu}

Beberapa penelitian terdahulu terkait dengan analisa rasio keuangan dengan metode radar antara lain:

1. Penelitian yang dilakukan oleh Bambang Hermanto yang mengolah data dari skripsi FE UI yang disusun oleh Gultom dengan judul "Penerapan Analisis Diskriminan untuk menentukan peubah terkendali yang mempengaruhi rasio keuangan perusahaan". Hasil dari penelitian ini berhasil menunjukkan suatu metode memvisualisasikan analisa rasio keuangan secara grafis.

2. Penelitian yang dilakukan oleh Imam Listiyanto dan Benny Lianto melakukan penelitian dengan judul "Penilaian kinerja dengan analisa rasio metode radar" (study kasus pada industri textile dan garmen). Analisa study dilakukan untuk membandingkan pola rasio keuangan untuk tahun 1993 dan 1995. Hasil dari penelitian menunjukkan kinerja keuangan perusahaan textile yang terdaftar pada bursa efek cukup baik. Berdasarkan visualisasi grafik terlihat beberapa aspek dari rasio keuangan telah menjauh dari titik pusat. Penelitian ini memperkuat penelitian Bambang Hermanto bahwa Analisa kinerja dengan metode radar dapat diaplikasi dalam penganalisa kinerja keuangan pada suatu industri.

3. Penelitian yang dilakukan oleh Elizabeth $S$ Darmawan dengan judul "Membedakan aspek rasio dari data keuangan dan non keuangan dari aspek metode radar". Hasil dari penelitian bahwa analisa rasio data non keuangan dengan metode radar belum terlalu optimum. Sebaliknya analisa rasio data keuangan semakin mempertegas aplikasi metode radar dapat digunakan untuk menilai kinerja pada industri.

Jurnal Sekuritas, Vol.1, No.4, Juni 2018 


\section{Kerangka Pemikiran Penelitian}

Uma Sekaran dalam bukunya Business Research (1992) yang dikutip Sugiyono ( 2012: 88) mengemukakan bahwa, kerangka berpikir merupakan model konseptual tentang bagaimana teori berhubungan dengan berbagai factor yang telah diidentifikasi sebagai masalah yang penting. Kerangka pemikiran juga merupakan alur alur pemikiran yang logis dalam membangun suatu kerangka berpikir sehingga hipotesa dari penelitian yang akan dilakukan dapat diprediksi hasilnya

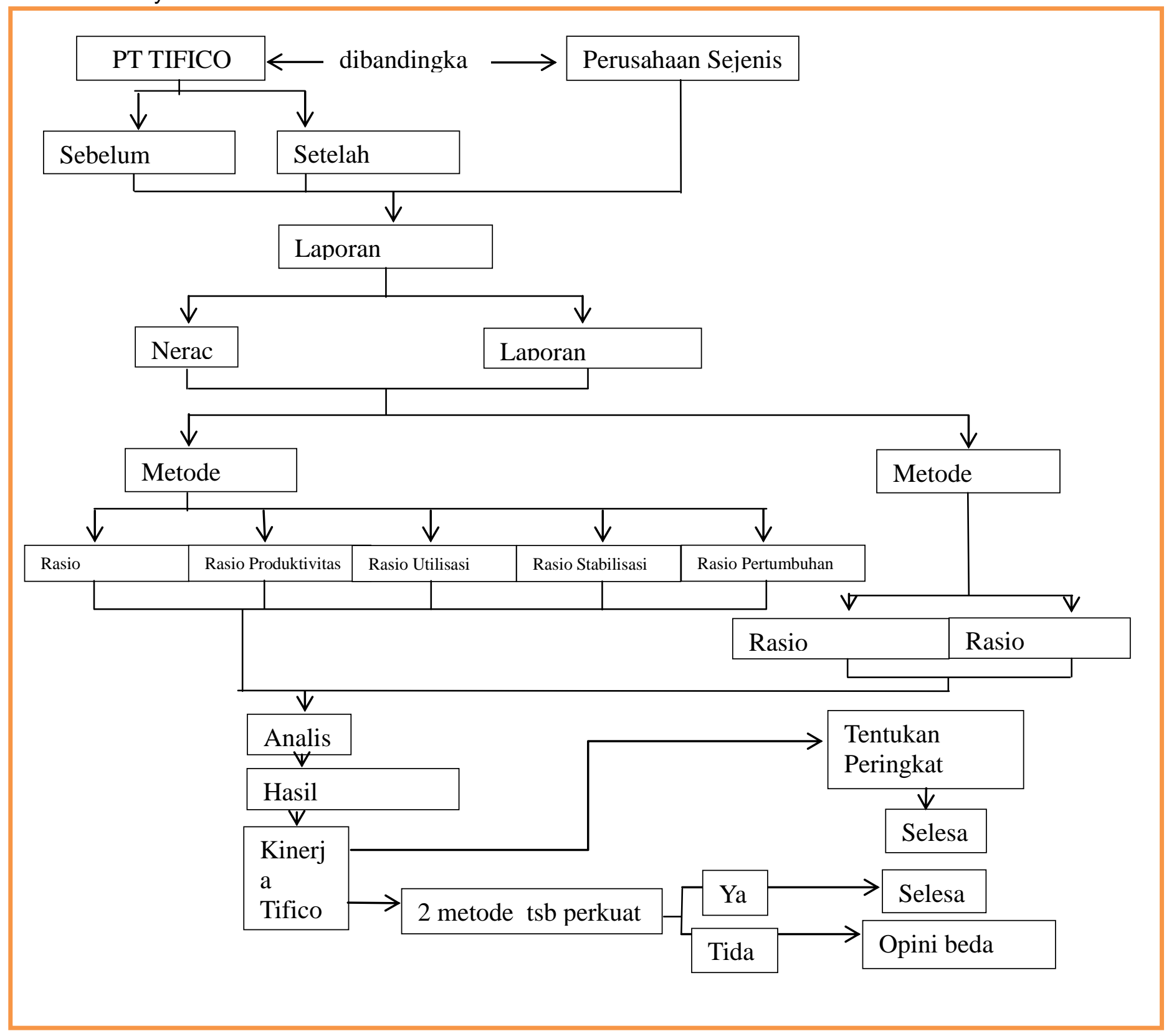




\section{E. Metode Penelitian}

\subsection{Pendekatan Penelitian}

Penelitian yang akan dilakukan ini merupakan jenis penelitian deskriptif. Penelitian deskriptif menurut Nazir (2003: 54) adalah suatu penelitian yang menerapkan suatu metode atau cara dalam meneliti suatu object, suatu kelompok, suatu pemikiran ataupun suatu peristiwa yang terjadi pada saat ini.

\subsection{Object Penelitian}

Object yang menjadi fokus pada penelitian ini yaitu Perusahaan PT Tifico Fiber Indonesia yang bergerak dalam industri Polyester dan perusahaan yang sejenis yang terdaftar dalam bursa efek Indonesia yaitu :

1. PT Tifico Fiber Indonesia Tbk.(Sebelumnya PT Tifico Indonesia Fiber Tbk).

2. PT Indorama Synthetics Tbk,

3. PT Polychem Indonesia Tbk.

4. PT Asia Pacific Fibers Tbk

\subsection{Jenis dan Data Sumber Data}

\section{a. Jenis Data}

Jenis data yang digunakan dalam penelitian ini berupa data quantitatif yaitu berupa laporan neraca dan laporan laba /Rugi periode 2006 2009 untuk PT Tifico sebelum akusisi dan periode 2010 2014 untuk PT Tifico setelah akuisisi dan perusahaan lainnya, serta laporan laporan lainnya yang menunjang yang didapat dari pihak pihak yang terkait pada PT Tifico Fiber Indonesia Tbk.

b. Sumber Data

Sumber sumber data yang digunakan dan dikumpulkan penulis berasal dari berbagai sumber yang ada baik dari manager Accounting berupa data laporan keuangan tahunan periode 2006 2009 maupun dari website Bursa efek Indonesia yaitu : http//:www.idx.co.id berupa laporan keuangan tahunan untuk periode 2010 2014 baik untuk PT Tifico setelah akuisisi maupun dari perusahaan perusahaan lainnya yang sejenis yang tersedia pada bursa efek Indonesia.

\subsection{Metode Pengumpulan Data}

Untuk mendapatkan data yang dibutuhkan, penulis melakukan 2 cara yaitu:

a. Study Pustaka,

Melakukan telah dan mengkaji dari berbagai literatur yang relevan dengan judul penelitian untuk mengumpulkan data data yang valid.

b. Dokumentasi,

Mencari dan mengumpulkan data data dari internet dengan browsing website Bursa Efek Indonesia. Data data yang dikumpulkan dari internet berupa laporan keuangan tahunan perusahaan untuk periode 2010 2014 yaitu : PT Tifico Fiber Indonesia Tbk, PT Polychem Indonesia Tbk, PT Asia Pacific Fiber Tbk, dan PT Indorama Synthetic Tbk. 


\subsection{Identifikasi Variabel Penelitian}

Variable yang digunakan dalam penelitian ini mengaplikasikan parameter parameter yang ada pada rasio keuangan yang tersebut dalam tabel 3.1 berikut ini.

Tabel 3.1 Tabulasi Variabel Penelitian

\begin{tabular}{|c|c|c|c|c|c|}
\hline No & $\begin{array}{l}\text { Metode } \\
\text { Rasio } \\
\end{array}$ & Variabel & Definisi & Parameter/Indikator & Formula \\
\hline \multirow[t]{7}{*}{1} & \multirow[t]{7}{*}{ Dupont } & \multirow[t]{2}{*}{ Aktivitas } & \multirow[t]{2}{*}{$\begin{array}{l}\text { Merupakan rasio untuk } \\
\text { mengukur efektivitas dan } \\
\text { efisien perusahaan dalam } \\
\text { menggunakan aset dan } \\
\text { harta yang dimiliki untuk } \\
\text { memperoleh pendapatan }\end{array}$} & $\begin{array}{c}\text { TATO (Total Asset } \\
\text { Turn over) }\end{array}$ & TATO $=\frac{\text { Net Sale }}{\text { Total Asset }}$ \\
\hline & & & & Equity Multiplier & $E M=\frac{\text { Total Asset }}{\text { Share holder }}$ \\
\hline & & \multirow[t]{5}{*}{ Profitabilitas } & \multirow{5}{*}{$\begin{array}{l}\text { Merupakan rasio yang } \\
\text { digunakan untuk } \\
\text { mengukur kemampuan } \\
\text { perusahaan dalam } \\
\text { mendapatkan } \\
\text { keuntungan pada periode } \\
\text { tertentu baik dengan } \\
\text { cara menjual produk } \\
\text { yang dihasilkan atau } \\
\text { dengan penjualan aset } \\
\text { perusahaan }\end{array}$} & $\begin{array}{c}\text { GPM (Gross Profit } \\
\text { Margin) }\end{array}$ & $\begin{array}{c}\text { (Sales - Cost of good s sales) } \\
\text { Sales }\end{array}$ \\
\hline & & & & $\begin{array}{l}\text { OPM (Operating } \\
\text { Profit Margin) }\end{array}$ & $\begin{array}{c}\text { (Sales - Cost of good s sales } \\
\text { - selling, general \& } \\
\text { administrative (SG\&A)costs] ) } \\
\text { OPM }=\text { - Sales }\end{array}$ \\
\hline & & & & $\begin{array}{c}\text { NPM (Net Profit } \\
\text { Margin) }\end{array}$ & $\begin{array}{c}\text { Net Income after Tax } \\
\text { Sales }\end{array}$ \\
\hline & & & & $\begin{array}{l}\text { ROI (Return of } \\
\text { Investment) }\end{array}$ & $R O I=N P M \times T A T O$ \\
\hline & & & & $\begin{array}{c}\text { ROE (Return of } \\
\text { Equity) }\end{array}$ & $\mathrm{ROE}=\mathrm{NPM} \times \mathrm{TATO} \times \mathrm{EM}$ \\
\hline \multirow[t]{7}{*}{2} & \multirow[t]{7}{*}{ Radar } & \multirow[t]{7}{*}{ Profitabilitas } & \multirow[t]{7}{*}{\begin{tabular}{|l|} 
Digunakan untuk \\
mengukur kemampuan \\
perusahaan \\
menghasilkan laba bersih \\
pada tingkat penjualan \\
dan periode tertentu
\end{tabular}} & $\begin{array}{c}\text { GPM (Gross Profit } \\
\text { Margin) }\end{array}$ & $\begin{array}{c}\text { (Sales - Cost of good s sales) } \\
\text { SPM }=\text { Sales }\end{array}$ \\
\hline & & & & $\begin{array}{l}\text { OPM (Operating } \\
\text { Profit Margin) }\end{array}$ & $\begin{array}{c}\text { (Sales - Cost of good s sales } \\
\text { - selling, general \& } \\
\text { administrative (SG\&A)costs] ) }\end{array}$ \\
\hline & & & & & Sales \\
\hline & & & & $\begin{array}{c}\text { NPM (Net Profit } \\
\text { Margin) }\end{array}$ & $\begin{array}{c}\text { Net Income after Tax } \\
\text { Sales }\end{array}$ \\
\hline & & & & $\begin{array}{l}\text { ROI (Return of } \\
\text { Investment) }\end{array}$ & ROI = NPM $\times$ TATO \\
\hline & & & & $\begin{array}{l}\text { ROE (Return of } \\
\text { Equity) }\end{array}$ & ROE = NPMXTATO $\times$ EM \\
\hline & & & & Sales to Expense & $\begin{array}{c}\text { Sales } \\
\text { STE }=\frac{----}{\text { BiayaOperasi }}\end{array}$ \\
\hline
\end{tabular}


ISSN (online) : 2581-2777 \& ISSN (print) : 2581-2696 Tabel 3.1 Tabulasi Variabel Penelitian

\begin{tabular}{|c|c|c|c|c|c|}
\hline No & $\begin{array}{c}\text { Metode } \\
\text { Rasio } \\
\end{array}$ & Variabel & Definisi & Parameter/Indikator & Formula \\
\hline \multirow[t]{4}{*}{2} & \multirow[t]{4}{*}{ Radar } & \multirow[t]{4}{*}{ Produktivitas } & \multirow{4}{*}{$\begin{array}{l}\text { Merupakan rasio yang } \\
\text { mencerminkan faktor } \\
\text { produktivitas karyawan } \\
\text { yang berada dalam } \\
\text { perusahaan }\end{array}$} & Sales per Employee & SPE $=\frac{\text { Sales }}{- \text { Jumlah karyawan tetap }}$ \\
\hline & & & & $\begin{array}{l}\text { Net Added Value } \\
\text { per employee }\end{array}$ & $\begin{array}{c}\text { Operating profit+Salaries, } \\
\text { wages, Payroll expense }\end{array}$ \\
\hline & & & & Equipment to labor & $\mathrm{E} / \mathrm{L}=\frac{\text { Equipment }}{\mathrm{Labour}(\text { Wages })}$ \\
\hline & & & & $\begin{array}{l}\text { Net Added Value } \\
\text { per total wages }\end{array}$ & $\begin{array}{c}\begin{array}{l}\text { Operating profit + } \\
\text { Salaries, Wages,Pay roll } \\
\text { expense }\end{array} \\
\text { NAV/W }\end{array}$ \\
\hline & & \multirow[t]{6}{*}{ Utilisasi Aset } & \multirow{6}{*}{$\begin{array}{l}\text { Merupakan rasio yang } \\
\text { digunakan untuk } \\
\text { mengukur effisiensi } \\
\text { perusahaan dalam } \\
\text { memperoleh pendapatan } \\
\text { dari aset yang dimilikinya } \\
\text { pada periode tertentu }\end{array}$} & $\begin{array}{c}\text { TATO (Total Asset } \\
\text { Turn over) }\end{array}$ & TATO $=\frac{\text { Net Sale }}{\text { Total Asset }}$ \\
\hline & & & & ITO (Inventory Turn & ITO $=$ \\
\hline & & & & over) & Inventory rata rata \\
\hline & & & & $\begin{array}{l}\text { ARTO (Account } \\
\text { Receivable Turn } \\
\text { over) }\end{array}$ & $\begin{array}{c}\text { NetCredit Sales } \\
\text { ARTO }=\text { - } \\
\text { Account Receivable rata }\end{array}$ \\
\hline & & & & $\begin{array}{l}\text { WCTO (Working } \\
\text { capital turn over) }\end{array}$ & $\begin{array}{l}\text { NetSales } \\
\text { WCTO }=----------1 \text { kali } \\
\quad(\text { Aset lancar- Liabilitas Iancar }\end{array}$ \\
\hline & & & & $\begin{array}{l}\text { FATO } \\
\text { (Fixed assets Turn } \\
\text { over) }\end{array}$ & FATO $=\frac{\text { Netsales }}{\text { Aset Tetap }}$ \\
\hline & & \multirow{5}{*}{$\begin{array}{l}\text { Stabilitas } \\
\text { (Gabungan } \\
\text { antara } \\
\text { Solvabilitas } \\
\text { dan } \\
\text { Liquiditas) }\end{array}$} & \multirow{5}{*}{$\begin{array}{l}\text { Merupakan rasio yang } \\
\text { digunakan untuk } \\
\text { mengukur kemampuan } \\
\text { perusahaan dalam } \\
\text { melaksanakan semua } \\
\text { kewajibannya pada } \\
\text { waktu yang telah } \\
\text { ditentukan. }\end{array}$} & $\begin{array}{l}\text { Current Ratio } \\
\text { (Rasio lancar) }\end{array}$ & $\begin{array}{c}\text { Aset Lancar } \\
\text { CR }=-------100 \% \\
\text { Liabilitas Lancar }\end{array}$ \\
\hline & & & & $\begin{array}{c}\text { Interest Charge } \\
\text { Ratio (ICR) }\end{array}$ & $\begin{array}{c}\text { Biaya bunga (tahun ini - tahun lalu) } \\
\text { Biaya bunga tahun lalu }\end{array}$ \\
\hline & & & & Quick Ratio (QR) & $\mathrm{QR}=\frac{(\text { Aset lancar-Persediaan) }}{\text { Kewajiban lancar }}$ \\
\hline & & & & $\begin{array}{l}\text { Debt to Equity Ratio } \\
\text { (DER) }\end{array}$ & DER $=\frac{\text { Hutang jangka panjang }}{\text { Modal sendiri }}$ \\
\hline & & & & Cash Ratio (C R) & $C R=\frac{(\text { Kas dan surat berharga) }}{\text { Hutang lancar }}$ \\
\hline & & \multirow[t]{4}{*}{$\begin{array}{l}\text { Potensi } \\
\text { Pertumbuhan }\end{array}$} & \multirow{4}{*}{$\begin{array}{l}\text { Merupakan rasio yang } \\
\text { digunakan untuk } \\
\text { mengukur pertumbuhan } \\
\text { bisnis perusahaan yang } \\
\text { terindikasi dari } \\
\text { peningkatan pendapatan } \\
\text { (Income) dan naiknya } \\
\text { harga saham dari } \\
\text { perusahaan tersebut. }\end{array}$} & \multirow[b]{2}{*}{$\begin{array}{c}\text { Net Added Value to } \\
\text { sales Growth }\end{array}$} & SG $=\frac{\text { Sales (tahun ini - tahun lalu) }}{\text { Sales tahun lalu }}$ \\
\hline & & & & & NAV/SG $=\frac{\begin{array}{c}\text { Operating profit+Salaries, } \\
\text { Wages Pay roll Expense) }\end{array}}{\text { Sales Growth }}$ \\
\hline & & & & $\begin{array}{c}\text { NIAT Increase Ratio } \\
\text { (Net Income after } \\
\text { Tax) }\end{array}$ & $\begin{array}{l}\text { Income aftertax(tahun ini - tahun lalu } \\
\text { NIAT = Sales tahun lalu }\end{array}$ \\
\hline 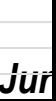 & nal $\mathbf{S e}$ & & & $\begin{array}{c}\text { Net Worth increase } \\
\text { Ratio }\end{array}$ & 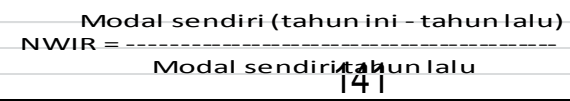 \\
\hline
\end{tabular}




\section{F. Hasil Penelitian Dan Pembahasan}

\section{Hasil Penelitian}

\section{Object Penelitian}

PT. TIFICO merupakan salah satu produsen pioner serat sintetis polyester yang terkemuka di Indonesia. Perusahaan ini memproduksi Polyester saat ini 200.000 Ton/tahun. Persetujuan pendirian perusahaan ini diberikan oleh Presiden Republik Indonesia pada tanggal 25 September 1973, dan secara resmi perusahaan ini didirikan pada tanggal 25 Oktober di tahun yang sama.

\section{Visi, Misi, dan Nilai}

Visi

Menjadikan Tifico sebagai produsen serat polyester yang unggul di pasar Domestik dan Internasional

\section{Misi}

Menghasilkan produk bermutu tinggi dengan harga yang kompetitif serta pengiriman yang tepat waktu

\section{Analisis Kinerja Keuangan Menggunakan Metode Dupont}

Perhitungan parameter rasio pada metode Dupont untuk menilai kinerja yaitu:

\section{a. Analisa Aktivitas.}

Analisa untuk mengukur sejauh mana perusahaan mengelola aset untuk memperoleh pendapatan yang optimal. Data yang digunakan untuk menganalisa kemampuan mengelola aset tersebut yaitu Total Aset turn over (TATO).

Total Asset Turnover (TATO) PT Tifico sebelum dan sesudah Akuisisi dan Perusahaan Polyester Periode $2006 \sim 2009$ dan $2010 \sim 2014$

\begin{tabular}{|l|r|r|r|r|r|r|}
\hline \multicolumn{1}{|c|}{ Perusahaan } & \multicolumn{1}{c|}{2010} & $2006 / 2011$ & $2007 / 2012$ & $2008 / 2013$ & $2009 / 2014$ & $\overline{\mathbf{x}}$ \\
\hline TIFICO Teijin & & 1,01 & 1,14 & 1,51 & 1,33 & 1,25 \\
\hline TIFICO Fiber Indonesia & 1,51 & 1,04 & 0,94 & 0,84 & 0,83 & 1,03 \\
\hline POLYCHEM & 0,76 & 0,93 & 0,81 & 0,90 & 0,96 & 0,87 \\
\hline ASIA PACIFIC FIBER & 1,13 & 1,52 & 1,49 & 1,62 & 1,81 & 1,51 \\
\hline INDORAMA & 1,09 & 1,16 & 1,08 & 1,03 & 0,98 & 1,07 \\
\hline
\end{tabular}

Dari data PT Tifico sebelum akuisisi terlihat nilai TATO mengalami peningkatan, namun dari aset terlihat adanya penurunan nilai aset disamping nilai penjualan yang berfluktuatif. 


\begin{tabular}{|c|r|r|r|r|}
\hline \multicolumn{1}{|c|}{ Item } & \multicolumn{1}{c|}{ Unit : USD } \\
\hline Aset & & 2006 & 2008 & 2009 \\
\hline a. Lancar (Current asset) & $\mathbf{1 1 4 . 5 8 9 . 6 8 1}$ & $\mathbf{1 1 7 . 3 7 1 . 6 4 4}$ & $\mathbf{8 6 . 2 8 5 . 0 5 9}$ & $\mathbf{7 9 . 6 7 4 . 7 7 1}$ \\
\hline b. Tidak Lancar (Fix Asset) & 167.968 .683 & $\mathbf{1 5 1 . 6 9 6 . 7 7 5}$ & $\mathbf{1 1 2 . 8 9 1 . 9 6 2}$ & 106029502 \\
\hline Total Aset & $\mathbf{2 8 2 . 5 5 8 . 3 6 4}$ & $\mathbf{2 6 9 . 0 6 8 . 4 1 9}$ & $\mathbf{1 9 9 . 1 7 7 . 0 2 1}$ & $\mathbf{1 8 5 . 7 0 4 . 2 7 3}$ \\
\hline$\%$ Kenaikan Aset & - & $-4,77$ & $-25,98$ & $-6,76$ \\
\hline Penjualan & 285.400 .836 & 305.614 .528 & 300.895 .345 & 246.240 .007 \\
\hline
\end{tabular}

Ada 2 faktor penyebab penurunan nilai aset yaitu:

a. Penurunan nilai investasi disebabkan adanya project yang tidak berhasil (gagal) diimplementasikan tapi telah dikeluarkan pembiayaannya.

b. Adanya bebarapa perusahaan customer yang gagal bayar dan penurunan nilai produk disebabkan life time yang sudah over (expired).

Sebaliknya nilai TATO pada PT Tifico setelah akuisisi stabil.

\section{b. Analisa rasio profitabilitas}

Untuk mengukur kemampuan sebuah perusahaan untuk memperoleh keuntungan selama periode tertentu dapat dilakukan dengan melalui data data yang diperoleh dari perolehan atau pencapaian antara lain Penjualan, Modal dan Aset perusahaan. Penilaian rasio Profitabilitas tergambar dari perhitungan GPM (gross Profit margin) dan NPM (Net profit margin) sebagai berikut:

Gross Profit Margin(GPM) PT Tifico sebelum dan sesudah Akuisisi dan Perusahaan Polyester

Periode $2006 \sim 2009$ dan 2010 2014

\begin{tabular}{|c|c|c|c|c|c|c|}
\hline Perusahaan & 2010 & $2006 / 2011$ & $2007 / 2012$ & $2008 / 2013$ & $2009 / 2014$ & $\overline{\mathrm{x}}$ \\
\hline TIFICO Teijin & & $(5,53)$ & 0,65 & $(4,82)$ & 0,04 & $(2,42)$ \\
\hline TIFICO Fiber Indonesia & 5,37 & 6,38 & 3,45 & $(0,46)$ & 0,29 & 3,01 \\
\hline POLYCHEM & 5,26 & 12,75 & 4,20 & 2,91 & $(3,52)$ & 4,32 \\
\hline ASIA PACIFIC FIBER & 7,43 & 7,00 & $(1,00)$ & $(3,60)$ & $(2,78)$ & 1,41 \\
\hline INDORAMA & 10,22 & 5,33 & 6,60 & 8,44 & 10,36 & 8,19 \\
\hline
\end{tabular}

Net Profit Margin (NPM) PT Tifico sebelum dan sesudah Akuisisi dan Perusahaan Polyester

Periode 2006 2009 dan 2010 2014

\begin{tabular}{|l|r|r|r|r|r|r|}
\hline \multicolumn{1}{|c|}{ Perusahaan } & \multicolumn{1}{c|}{2010} & $2006 / 2011$ & $2007 / 2012$ & $2008 / 2013$ & $2009 / 2014$ & \multicolumn{1}{c|}{$\bar{x}$} \\
\hline TIFICO Teijin & & $(18,06)$ & $(10,49)$ & $(19,20)$ & $(7,01)$ & $(13,69)$ \\
\hline TIFICO Fiber Indonesia & 3,62 & 8,20 & 2,25 & $(3,08)$ & $(1,64)$ & 1,87 \\
\hline POLYCHEM & 1,02 & 5,84 & 1,72 & 0,39 & $(5,50)$ & 0,69 \\
\hline & & & & & & \\
ASIA PACIFIC FIBER & 7,51 & $(0,98)$ & $(5,35)$ & $(5,26)$ & $(16,05)$ & $(4,03)$ \\
\hline INDORAMA & 4,19 & 1,21 & 0,06 & 0,10 & 0,56 & 1,22 \\
\hline
\end{tabular}

Jurnal Sekuritas, Vol.1, No.4, Juni 2018 
PT.Tifico sebelum akuisisi mengalami fluktuasi rugi disebabkan pada periode tersebut terjadi peningkatan beban biaya diantaranya yaitu:

a. Biaya energi, disebabkan harga minyak dunia yang melambung hingga mencapai \$150/barrel, dan frekuensi keabnormalan power plant PLTU yang masih tinggi yang meyebabkan pemakaian bahan bakar minyak tinggi dalam kondisi harga yang mahal.

b. beban hutang yang besar dari periode sebelumnya disebabkan dampak dari kegagalan dari beberapa project.

\section{c. Analisa ROI (Return of Investment).}

Parameter untuk mengukur kemampuan perusahaan dalam menghasilkan keuntungan dari penggunaan aset yang tersedia. Data ROI sebagai berikut:

Returm of Investment (ROI) PT Tifico sebelum dan sesudah Akuisisi dan Perusahaan Polyester Periode 2006 2009 dan $2010 \sim 2014$

\begin{tabular}{|l|r|r|r|r|r|r|}
\hline \multicolumn{1}{|c|}{ Perusahaan } & \multicolumn{1}{|c|}{2010} & $2006 / 2011$ & $2007 / 2012$ & \multicolumn{1}{c|}{$2008 / 2013$} & \multicolumn{1}{c|}{$2009 / 2014$} & \multicolumn{1}{|c|}{} \\
\hline TIFICO Teijin & & $(18,24)$ & $(11,92)$ & $(29,01)$ & $(9,29)$ & $(17,12)$ \\
\hline TIFICO Fiber Indonesia & 5,45 & 8,51 & 2,11 & $(2,60)$ & $(1,36)$ & 2,42 \\
\hline POLYCHEM & 0,77 & 5,41 & 1,40 & 0,35 & $(5,30)$ & 0,53 \\
\hline ASIA PACIFIC FIBER & 8,48 & $(1,48)$ & $(7,96)$ & $(8,54)$ & $(29,07)$ & $(7,71)$ \\
\hline INDORAMA & 4,57 & 1,40 & 0,06 & 0,10 & 0,54 & 1,34 \\
\hline
\end{tabular}

Nilai ROI Tifico sebelum akuisisi $-17,12 \%$ yang menunjukkan penjualan setiap $\$ 100$, maka perusahaan kerugian sebesar $\$ 17,12$. Sebaliknya Tifico setelah akuisisi mempunyai penilaian ROI 2,42 \%. Dari data adanya penurunan nilai ROI pada 2 tahun terakhir PT tifico setelah akuisisi disebabkan faktor eksternal yaitu kenaikan nilai bahan baku yang menyebabkan tinggi nilai bahan baku yang berdampak pada nilai penjualan yang menurun pada 2 periode tersebut.

\section{d. Analisa ROE (Return of Equity).}

Suatu parameter untuk mengukur kemampuan perusahaan untuk mendapatkan keuntungan dari jumlah aset yang dimiliki oleh Investor (pemilik perusahaan).

Data ROE sebagai berikut:

Return of Equity (ROE) PT Tifico sebelum dan sesudah Akuisisi dan Perusahaan Polyester Periode $2006 \sim 2009$ dan $2010 \sim 2014$

\begin{tabular}{|c|c|c|c|c|c|c|}
\hline Perusahaan & 2010 & $2006 / 2011$ & $2007 / 2012$ & $2008 / 2013$ & 2009/2014 & $\overline{\mathbf{x}}$ \\
\hline TIFICO Teijin & & $(2,13)$ & 2,09 & 0,65 & 1,33 & 0,49 \\
\hline TIFICO Fiber Indonesia & 0,12 & 0,04 & 0,01 & $(0,03)$ & $(0,02)$ & 0,03 \\
\hline POLYCHEM & 1,57 & 3,12 & 0,13 & 0,14 & $(0,03)$ & 0,99 \\
\hline ASIA PACIFIC FIBER & 0,01 & 0,01 & 0,07 & 0,06 & 0,05 & 0,04 \\
\hline INDORAMA & 0,09 & 0,02 & 0,04 & 0,07 & 0,08 & 0,06 \\
\hline
\end{tabular}

Penilaian ROE pada PT Tifico sebelum akuisisi 0,49 lebih baik dari setelah akuisisi. Ini disebabkan penurunan aset yang significan sebagaimana tersebut pada tabel diatas.

Berdasarkan data data analisa rasio diatas dapat disimpulkan penilaian kinerja perusahaan dengan metode Dupont sebagai mana tersebut pada tabel berikut : 
Data ROI dan ROE PT Tifico sebelum dan setelah akuisisi serta perusahaan sejenis

\begin{tabular}{|c|c|c|c|c|c|}
\hline \multirow[b]{2}{*}{ Perusahaan } & \multirow[b]{2}{*}{ Periode } & \multicolumn{2}{|c|}{ ROI } & \multicolumn{2}{|c|}{ ROE } \\
\hline & & ta Perhitung & andar Indus & \begin{tabular}{|c|} 
Data \\
Perhitunga \\
$\mathrm{n}$ \\
\end{tabular} & $\begin{array}{l}\text { Standar } \\
\text { Industri }\end{array}$ \\
\hline TIFICO Teijin & $2006 \sim 2009$ & $-17,12$ & 4,65 & 0,49 & 8,5 \\
\hline TIFICO Fiber Indonesia & $2010 \sim 2014$ & 2,42 & 4,65 & 0,03 & 8,5 \\
\hline POLYCHEM & $2010 \sim 2014$ & 0,53 & 4,65 & 0,99 & 8,5 \\
\hline ASIA PACIFIC FIBER & $2010 \sim 2014$ & $-7,71$ & 4,65 & 0,04 & 8,5 \\
\hline INDORAMA & $2010 \sim 2014$ & 1,34 & 4,65 & 0,06 & 8,5 \\
\hline
\end{tabular}

-Sumber hasil pengolahan dibandingkan dengan Principle of

Managerial Finance Lawrence Gitman.

- Catatan: Perhitungan dengan mata uang USD

Tabel ROI dan ROE diatas menunjukkan PT Tifico sebelum akuisisi berkinerja sangat buruk yaitu nilai $\mathrm{ROI}-17,12 \%$ yang berarti peningkatan produksi akan menyebabkan peningkatan kerugian. Sebaliknya PT Tifico setelah akuisisi berkinerja normal dengan nilai ROI 2,42 \% yang berarti peningkatan produksi akan meningkatkan keuntungan perusahaan. Jika dibandingkan dengan perusahaan sejenis lainnya terlihat nilai ROI PT Tifico setelah akuisisi lebih besar yang berarti kinerjanya lebih baik dari perusahaan kompetitor tersebut. Namun jika dibandingkan dengan standar industri baik PT Tifico setelah akuisisi maupun perusahaan sejenis lainnya kondisi kinerjanya masih dalam kondisi belum sehat.

\section{Analisis Kinerja Keuangan Menggunakan Metode Radar.}

Data data hasil perhitungan dengan metode radar terangkum dalam gambar yang tersebut dibawah ini mencerminkan kinerja semua perusahaan yang dianalisa:

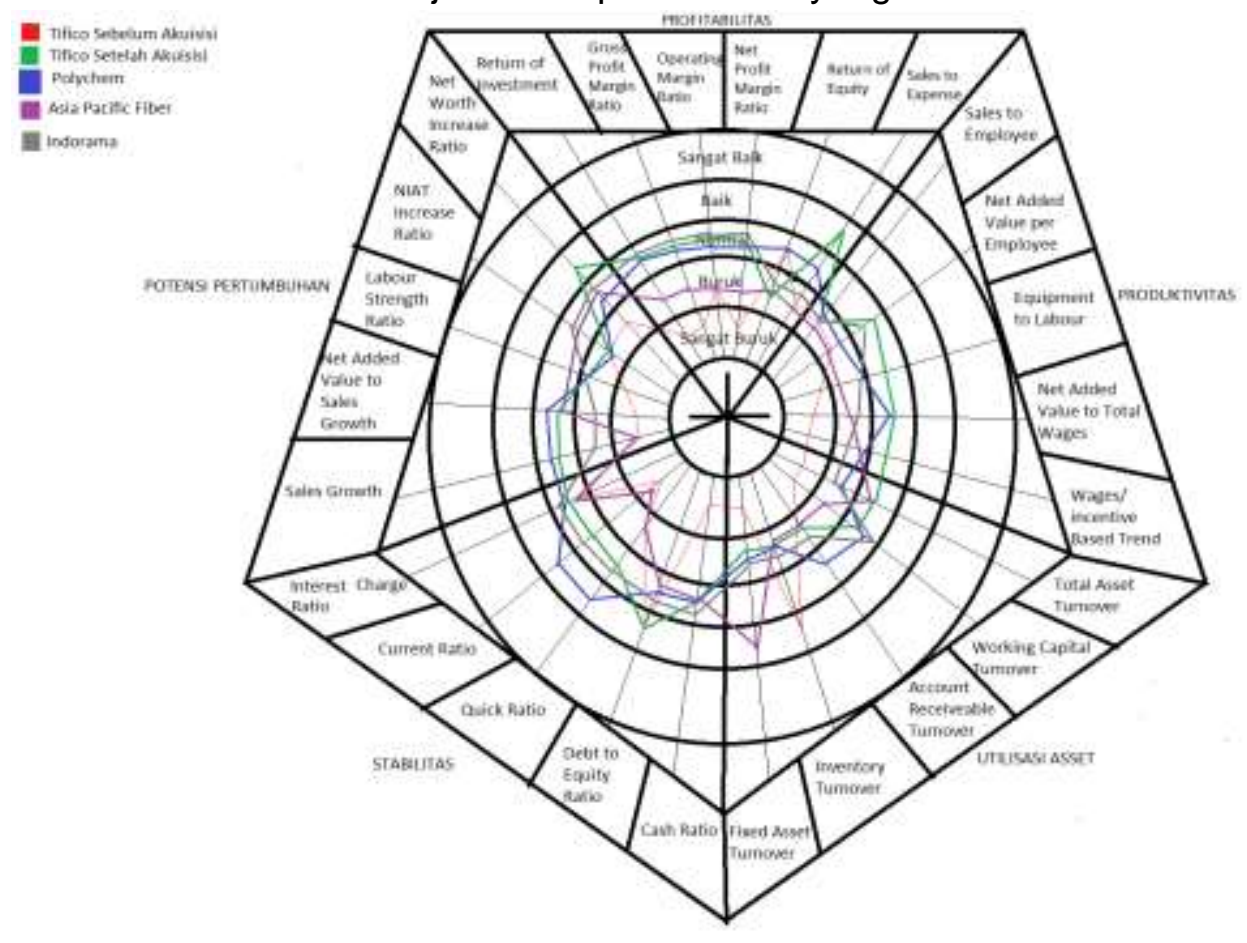

Jurnal Sekuritas, Vol.1, No.4, Juni 2018 
1. Analisa Rasio Profitabilitas.

Dari grafik Radar diatas terlihat secara umum pola diagram pancar masing masing aspek rasio PT Tifico sebelum Akuisisi mendekati pusat lingkaran. Ini bermakna kinerja Tifico sebelum Akuisisi pada periode 2006 2009 buruk. Untuk parameter rasio profitabilitas mendapatkan penilaian yang buruk. Ini menunjukkan management perusahaan tidak mampu menjalankan fungsinya dengan baik untuk memberikan keuntungan perusahaan.

Ada 2 faktor penyebab terpuruknya PT Tifico sebelum akuisisi yaitu:

a.Faktor Eksternal,

Terjadi resesi ekonomi dunia pada kurun 2007 2008 yang menyebabkan harga minyak dan bahan baku Polyester melambung tinggi.

b.Faktor Internal.

Gagalnya projek projek untuk menekan biaya produksi, dan banyaknya hutang customer yang tidak bisa ditagih.

Sebaliknya pada PT. Tifico setelah akuisisi berhasil dalam melakukan kebijakan kebijakan menekan kerugian perusahaan, diantaranya yaitu;

a.Memodifikasi dan memperbaiki secara menyeluruh PLTU (Turbin).

b.Kebijakan dalam hal pembelian barang dan penjualan produk.

2. Analisa Rasio Produktivitas

Rasio produktivitas merupakan suatu rasio yang mencerminkan indikasi produktivitas manusia di dalam perusahaan. Analisa rasio ini berhubungan dengan kapabilitas (kemampuan) manusianya dalam mendapatkan income dan expense yang dikeluarkan untuk hal tersebut. Semakin besar nilai parameter yang diperoleh dalam rasio produktivitas ini, maka semakin baik unjuk kerja (kinerja) manusia dalam perusahaan tersebut. Penilaian PT Tifico sebelum akuisisi dari grafik radar terihat mendekati pusat lingkaran yang bermakna Produktivitas juga tidak baik. Sebaliknya pada PT Tifico setelah akuisisi mendapat penilaian yang baik. Hal ini bisa dicapai karena ada beberapa kebijakan yang diambil perusahaan untuk menekan biaya kesejahteraan karyawan dengan mengembalikan biaya disesuaikan kembali ke dasar hukum Undang undang. 3. Analisa Rasio Utilisasi Aset.

Rasio Utilisasi aset merupakan suatu indikator atau alat ukur melihat sejauh mana effisiensi perusahaan dengan aset yang tersedia padanya untuk memperoleh pendapatan (income). Penilaian dari grafik Radar, PT Tifico sebelum akuisisi mendapat penilaian yang lebih baik dari setelah. Hal ini disebabkan beberapa faktor yang disebabkan kebijakan perusahaan yang diambil mengantisipasi kondis eksternal seperti :

a.Stop produksi disebabkan harga bahan baku yang tinggi dan harga jual yang stabil.

b.Penurunan nilai aset perusahaan.

c. Kredit macet customer.

d. Stock tinggi karena selektif ketat penjualan.

4. Analisa Rasio Stabilitas.

Rasio stabilitas merupakan penggabungan 2 rasio yaitu rasio solvabilitas dan rasio liquiditas. Rasio ini merupakan indikator untuk melihat kemampuan perusahaan untuk 
memenuhi kewajiban kewajiban jangka pendek dan melihat sumber pendanaan untuk pembelian barang barang operasional.

Dari grafik radar terlihat PT Tifico sebelum akuisisi bernilau buruk, hal disebabkan banyaknya hutang yang belum tertagih dan tidak bisa dikonversikan menjadi uang kas,dan berdampak pada biaya operasional dilaksanakan dengan menghutang lagi pada pihak ketiga. Sebaliknya pada PT Tifico setelah akuisisi, problem hutang penanganan hutang dapat diambil langkah yang tepat.

5. Analisa Rasio Pertumbuhan.

Rasio pertumbuhan merupakan indikator yang menunjukkan potensi pertumbuhan usaha riel yang tercermin dari meningkatnya jumlah pendapatan dan naiknya harga saham perusahaan tersebut.

Semua parameter pada Rasio pertumbuhan untuk PT Tifico sebelum akuisisi mendekati pusat grafik radar dan hal ini menunjukkan perusahaan tidak mempunyai prospek untuk meningkatkan kinerjanya. Dan sebaliknya penilaian untuk PT Tifico setelah akuisisi mendapatkan penilaian yang baik dan berpotensi untuk berkembang dimasa yang akan datang.

Merujuk pada penelitian yang dilakukan oleh Listyanto dan Wijaya (2003) mengenai"Penilaian kinerja dengan analisa rasio metode radar" (study kasus pada industri textile dan garmen). maka penulis membuat perhitungan untuk membuat peringkat berdasarkan tabel berikut:

Tabel 4. 1 Standar Klasifikasi Metode Radar

\begin{tabular}{|c|c|c|c|c|c|}
\hline Grade & A & B & $\overline{\mathbf{x}}$ & C & D \\
\hline Nilai & 5 & 4 & 3 & 2 & 1 \\
\hline Kategori & Sangat baik & Baik & Normal & buruk & Sangat Buruk \\
\hline
\end{tabular}

Perhitungan peringkat dapat dilakukan dengan membuat asumsi semua parameter rasio metode radar mempunyai bobot yang sama sehingga dapat dilakukan nilai rata rata terhadap masing masing rasio dan double rata rata semua rasio berdasarkan data perusahaan yang terkait.

Dari hasil perhitungan tersebut didapat hasil peringkat perusahaan seperti tersebut dibawah ini:

4. 2 Peringkat Kinerja Perusahaan Polyester periode $2006 \sim 2009$ dan $2010 \sim 2014$

\begin{tabular}{|r|l|c|c|c|c|}
\hline Peringkat & Nama Perusahaan & Periode Laporan keuangan & Penilaian & Kategori & Grade \\
\hline $\mathbf{1}$ & PT. Tifico setelah Akuisisi & $2010 \sim 2014$ & 3,00 & Normal & $\overline{\mathbf{X}}$ \\
\hline $\mathbf{2}$ & PT Polychem & $2010 \sim 2014$ & 2,87 & Normal & $\mathrm{C} \sim \mathrm{X}$ \\
\hline $\mathbf{3}$ & PT Indorama & $2010 \sim 2014$ & 2,57 & Normal & $\mathrm{C} \sim \mathrm{X}$ \\
\hline $\mathbf{4}$ & PT APF & $2010 \sim 2014$ & 2,3 & Buruk & $\mathrm{C} \sim \mathrm{X}$ \\
\hline $\mathbf{5}$ & PT. Tifico sebelum Akuisisi & $2006 \sim 2009$ & 1,86 & Buruk & $\mathrm{D} \sim \mathrm{C}$ \\
\hline
\end{tabular}




\section{Pembahasan.}

\section{Analisa Keuangan PT Tifico Sebelum dan Sesudah Akuisisi Menggunakan Metode Dupont.}

Berdasarkan perhitungan, data $\mathrm{ROI}$ rata rata untuk PT Tifico sebelum akuisisi yaitu $-17,12 \%$ dengan rentang dari periode $2006 \sim 2009$ yaitu $-9,29 \% \sim-29,01 \%$. Hal ini mengindikasikan upaya upaya yang dilakukan oleh managemen tidak sukses (gagal). Usaha usaha yangdilakukan managemen PT Tifico sebelum akuisisi, dan mengalami kegagalan yang penulis dapatkan yaitu:

a. Penggantian sumber listrik dari Diesel engine menjadi PLTU yang menggunakan bahan bakar batu bara

b. Program pensiun dini dengan sasaran untuk menurunkan jumlah karyawan hingga $40 \%$

c. Program automatisasi mesin dengan sasaran menindak lanjut dari program pensiun dini.

d. Program penurunan biaya produksi (Cost down) pada semua sektor proses.

e. Program lainnya.

Semua program tersebut diatas membutuhkan dana investasi yang besar tapi hasil dari program tersebut tidak berhasil sehingga beban biaya produksi dan biaya lainnya tetap tinggi. Sebaliknya PT Tifico setelah akuisisi mendapatkan penilaian yang 2,42 \%. Nilai ini jauh diatas sebelum akuisisi. Nilai ROI ini belum dikategorikan baik, hal ini disebabkan faktor eksternal. Untuk meningkatkan hasil ROI ini upaya yang bisa dilakukan khususnya untuk mengantisipasi problema biaya tinggi dari faktor eksternal (kenaikan harga bbm dan harga bahan baku), yaitu

a. Membuat produk pertambahan nilai yang tinggi.

b.Bekerja sama dengan pihak ilmuwan untuk menemukan barang baru dari produk perusahaan polyester seperti sepatu olah raga, jok mobil, ban kenderaan dari polyester dan lain sebagainya.

c.Peningkatan jumlah ekspor produk dengan peningkatan qualitas produk.

\section{Analisa Keuangan PT Tifico Sebelum dan Sesudah Akuisisi Menggunakan Metode Radar.}

Berdasarkan data perhitungan dengan metode radar, hasil penilaian pada PT Tifico sebelum akuisisi dan setelah akuisisi dapat diuraikan sebagai berikut:

\section{a. Rasio Profitabilitas.}

Nilai perhitungan semua item rasio profitabilitas PT Tifico sebelum akuisisi yaitu 1,67 dan terkategori sangat buruk. Sebaliknya PT Tifico setelah akuisisi terkategori normal. Dari 6 parameter rasio profitabilitas ini hanya parameter ROE yang terkategori buruk. Faktor penyebab hal ini terjadi dari biaya pokok produksi yang tinggi serta diiringi dengan naiknya harga bahan baku. Untuk mengantisipasi hal tersebut perlu dilakukan tindakan tindakan yang progresif seperti:

a. Penggantian bahan bakar murah dari tumbuh tumbuhan, atau installasi Pembangkit listrik tenaga Surya (PLTS).

b. Membuatkan bahan baku PTA (Pure Threthalate Acid) dan MEG (Methyl Ethylene Glycol) yang bukan berasal dari hereditas(turunan) Bahan bakar minyak. 
c. Melakukan produk inovatif bukan saja melakukan diversifikasi produk untuk meningkat nilai tambah (added value product) tapi juga perlu dikembangkan produk baru dari produk polyester yang dihasilkan.

\section{b. Rasio Produktivitas.}

Nilai perhitungan semua item rasio produktivitas PT Tifico sebelum akuisisi yaitu 1,67 dan terkategori sangat buruk. Faktor utama penyebab produktivitas karyawan lebih utama disebabkan faktor peralatan baik peralatan proses maupun pendukung proses mengalami keabnormalan khususnya terkait dengan keabnormalan PLTU yang berbahan bakar batu bara. Dampak yang timbul dari keabnormalan ini menyebabkan hasil produksi menurun dan hanya menghasilkan produk dengan grade sangat rendah (waste). Sebaliknya PT Tifico setelah akuisisi terkategori normal akibat revitalisasi yang dilakukan menunjukkan hasil yang positif.

\section{c. Rasio Utilisasi Aset.}

Nilai perhitungan semua item rasio utilisasi aset PT Tifico sebelum akuisisi yaitu 1,75 dan terkategori sangat buruk. Faktor penyebab utama gagalnya program otomatisasi mesin dan sering terjadi keabnormalan mesin Turbin, sehingga pemanfaatan aset tidak dapat dioptimalkan. Sebaliknya pada PT Tifico setelah akuisisi mendapat penilaian yang normal dampak dari berhasilnya revitalisasi mesin yang bermasalah khususnya mesin PLTU berbahan bakar batu bara.

\section{d. Rasio Stabilitas.}

Nilai perhitungan semua item rasio Stabilitas PT Tifico sebelum akuisisi terkategori buruk dsebabkan faktor kredit macet dari customer, dan penundaan pembayaran customer cukup significant, sebaliknya PT Tifico setelah akusisi terkategori normal. Perbaikan penilaian ini dari kebijakan penjualan pada customer yang mempunyai track record buruk dengan sistem khusus.

\section{e. Rasio Pertumbuhan.}

Nilai perhitungan semua item rasio pertumbuhan PT Tifico sebelum akuisisi yaitu 1,5 dan terkategori sangat buruk. Hal ini disebabkan faktor rendahnya rasio penjualan dari periode satu ke periode berikutnya serta tinggi beban biaya khususnya biaya pengadaan energi dan bahan bakuserta kerusakan mesin yang sering terjadi Sedangkan PT Tifico sesudah akuisisi secara keseluruhan item rasio Pertumbuhan mendapatkan penilaian baik 3,0.

\section{Analisa Pembanding dengan perusahaan polyester sejenis setelah akuisisi.}

Berdasarkan analisa rasio dengan metode Dupont sebagaimana tercantum pada lampiran perhitungan menunjukkan penilaian rata rata item ROI untuk PT Tifico setelah akuisisi yang tertinggi dibandingkan dengan perusahaan polyester lainnya, sedangkan penilaian ROE untuk semua perusahaan mendapat penilaian yang hampir sama. Berdasarkan data ini bisa disimpulkan managemen PT Tifico setelah akuisisi dengan kendala awal yang ada pada saat pengambil alihan dapat melakukan perbaikan kinerja yang sangat significant dan dapat menaikkan peringkat kinerja dari peringkat ke lima menjadi peringkat pertama dari perusahaan polyester yang terdapat pada Bursa Efek Indonesia.Dari data data diatas walaupun kinerja PT Tifico setelah akuisisi mengalami perbaikan yang signifikan namun jika dibandingkan dengan standard industri manufakture, kinerja PT. Tifico setelah akuisisi masih terkategori kurang sehat (kurang baik) sehingga diperlukan tindakan tindakan yang progresif. 
Secara umum permasalahan Perusahaan polyester menyangkut 3 item rasio saja yaitu:

a. Produktivitas.

b. Utilisasi Aset

c. Pertumbuhan.

Permasalahan yang utama dari tiga rasio tersebut diatas menyangkut masalah besarnya penjualan dan beban biaya yang tinggi yang disebabkan faktor ekternal perusahaan yaitu bahan bakar dan baku yang berfluktuasi. Kondisi ini merupakan fenomena yang terjadi pada seluruh perusahaan polyester. Untuk mengatasi hal tersebut maka perlu dilakukan upaya upaya yang progresif dan terintegrasi sehingga akar masalah yaitu penggunaan dari bahan bakar yang tinggi serta bahan baku yang juga merupakan hereditas(turunan) dari bahan bakar dapat dikurangi. Berdasarkan ide tersebut maka hal yang mendasar yang dilakukan yaitu melakukan inovatif berupa menggantikan sumber energi dan bahan baku dari bahan berbasis fosil baik bahan bakar minyak (solar) ataupun batu bara dengan sumber energi surya ataupun bahan bakar berbasis dari tumbuh tumbuhan. Implementasi dari ide tindakan ini akan meningkatkan kinerja keuangan perusahaan Polyester

\section{G. Kesimpulan dan Saran}

1. Kesimpulan

1. Penilaian kinerja keuangan dengan metode Dupont.

Kinerja Perusahaan PT Tifico setelah akuisisi mengalami perbaikan yang significant dibandingkan dengan sebelum akuisisi.

2. Penilaian kinerja keuangan dengan metode Radar.

Kinerja PT Tifico setelah akuisisi memperoleh penilaian yang normal untuk 4 aspek rasio dengan metode radar, sebaliknya $\mathrm{PT}$ Tifico sebelum akusisi mendapat penilaian yang buruk untuk semua aspek rasio dengan metode radar.

3. Perbandingan Kinerja dengan perusahaan sejenis setelah Akuisisi.

Analisa dengan metode dupont, semua perusahaan yang menjadi object penelitian mempunyai kinerja yang hampir sama, hal ini menunjukkan persaingan diantara perusahaan tersebut sangat kompetitif. Sebaliknya analisa dengan metode radar dapat disimpulkan PT Tifico setelah akuisisi mempunyai kinerja yang lebih baik dibandingkan dengan perusahaan object penelitian lainnya, namun jika dibandingkan dengan standar kinerja industri manufaktur, kinerja PT Tifico masih terkategori kurang sehat.

\section{Saran}

1. Kondisi perusahaan PT Tifico setelah akuisisi walaupun membaik tapi belum terkategori sehat dari sisi kinerja industri secara umum, pihak manajemen perlu melakukan usaha usaha yang progresif untuk mengatasi akar permasalahan perusahaan kurang sehat.

2. Pengelolaan perusahaan berdasarkan kompetensi karyawan harus lebih diimplemetasikan serta sikap untuk perhatian (awareness) pada karyawan harus lebih digiatkan agar peran serta kapabilitas semua pelaksana / pelaku kegiatan perusahaan dapat optimal. 


\section{K. Daftar Pustaka}

Agnes,Sawir, 2005. Analisa Kinerja Keuangan dan Perencanaan keauangan Perusahaan edisi 5 , PT. Gramedia Pustaka Utama, Jakarta

Dwi Prastowo, 2008. Analisis Laporan Keuangan, Edisi Kedua Sekolah Tinggi IImu Manajemen

Gitman, Lawrence J.dan Chad J Zutter 2009. Principle of Managerial Finance, third edition Global Edition: Pearson education limited United States:

Harahap, Sofyan S. 2007. Analisis Kritis atas Laporan Keuangan. Edisi Kesatu. PT. Raja Grafindo Persada. Jakarta

Harahap, Sofyan Syafri. 2009. "Analisis Kritis Atas Laporan Keuangan". Jakarta:RajaGrafindo Persada

Ikatan Akuntan Indonesia. 2012. Standar Akuntansi keuangan per 1 Juni 2012, Salemba Empat, Jakarta.

Ikatan Akuntan Indonesia, 2009. Laporan Keuangan Interim. Jakarta : Salemba Empat. Irham Fahmi. 2011. Analisis Laporan Keuangan, Alfabeta, Bandung.

Irawati Susan, 2005, Manajemen Keuangan, Pustaka, Bandung

Kasmir, 2008. Analisis Laporan Keuangan, Jakarta:Rajawali Pers.

Kasmir, 2010. Analisis Laporan Kenangan, Edisi Pertama, Raja Grafindo Persada, Jakarta.

Lukman Syamsudin. 2001. Manajemen Keuangan Perusahaan (Konsep Aplikasi Dalam Perencanaan, Pengawasamn, dan Pengambilan Keputusan). Jakarta: PT.Raja Grafindo Persada.

Munawir, 2011. Analisa Laporan Keuangan, Edisi Keempat, Liberty, YKPN, Yogyakarta.

Moch.Nazir, 2003. Metode Penelitian, edisi kelima. Jakarta: Ghalia Indonesia.

Mulyono, Teguh Pudjo. (1995). Analisa Laporan Keuangan Untuk Perbankan, Edisi revisi III. Jakarta: Penerbit Djambatan.

Michael A. Hitt dkk. 2002. Merger dan Akuisisi: Panduan Meraih Laba Bagi Para Pemegang Saham, Edisi 1,PT RajaGrafindo Persada, Jakarta

P.S. Sudarsanam, (1999), The Essence of Merger and Acquisition, Edisi Pertama, Cetakan Pertama, Alih Bahasa : Rahmad Herutomo, (1999), ANDI, Yogyakarta

Rahardjo, Budi, 2007, Keuangan dan Akuntansi, Edisi Pertama, Cetakan Pertama, Graha IImu, Yogyakarta.

Roni Setyawan, Kinerja keuangan dengan menggunakan metode radar pada pusat konservasi tumbuhanBogor, Jurnal keuangan Usahawan no 9 tahun ke 35 september 2006

Riyanto, Bambang, 2008. Dasar-dasar Pembelajaran Perusahaan, BPFE, Yogyakarta.

Rahardjo, Budi, 2007, Keuangan dan Akuntansi, Edisi Pertama, Cetakan Pertama, Graha IImu, Yogyakarta

Sawir, 2008. Analisa Kinerja Keuangan dan Perencanaan keauangan Perusahaan, PT. Gramedia Pustaka Utama, Jakarta

Sutrisno. 2007. Manajemen Keuangan, Ekonesia, Yogyakarta.

Syamsuddin, L. 2009. Manajemen Keuangan Perusahaan Konsep Aplikasi dalam: Perencanaan, Pengawasan, dan Pengambilan Keputusan, Penerbit PT. Raja Grafindo Persada, Jakarta.

Sundjaja, Ridwan dan Inge Barlian. 2002. Manajemen Keuangan Dua. Edisi Ketiga. Jakarta: PT Prenhallindo.

Sutrisno. 2003. Manajemen Keuangan (Teori, Konsep, dan Aplikasi). Edisi Pertama. Yogyakarta : EKONISIA.

Susan Irawati .2005.Manajemen Keuangan.Bandung : Penerbit Pustaka

Sawir, Agnes, 2009. Analisa Kinerja Keuangan dan Perencanaan keauangan Perusahaan, PT. Gramedia Pustaka Utama, Jakarta. 